\title{
Benthic macroinvertebrate communities in sites with native forest presence and absence in north Patagonia
}

\author{
Patricio De los Ríos-Escalante 1,2 (1D, Carlos Esse ${ }^{3}$ (i) , Rodrigo Santander-Massa ${ }^{4,5}$ (D), \\ Pablo Saavedra ${ }^{3}$ (10) \& Francisco Encina-Montoya ${ }^{2,6}$ (1)
}

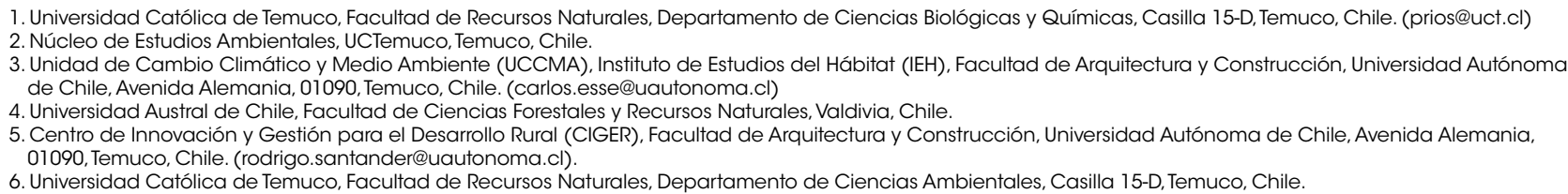

ABSTRACT. The benthic fauna in northern Patagonian streams is characterized by presence of water quality indicator species. The aim of the present study was characterized the benthic communities in streams associated to sites with presence of Nothofagus forests and with human intervention without Nothofagus forests using null models in ecology, unified neutral theory of biodiversity (UNTB) and unweighted pair group method with arithmetic mean (UPGMA). The results of species co-occurrence null model revealed that species associations are random, whereas the results of niche overlap null models revealed the presence of niche overlap. The UNTB results revealed low species number. The results of UPGMA revealed that species composition is specific for each site existing marked differences. The exposed results agree with results observed for central and northern Patagonian Chilean rivers, where the species composition is variable in according to surrounding basin properties and seasonal conditions.

KEYWORDS. Benthic macroinvertebrates, Nothofagus, communities, null models, aquatic insects.

RESUMO. Comunidades de macroinvertebrados bentônicos em locais com presença e ausência de floresta nativa no norte da Patagônia. A fauna bentônica nos córregos do norte da Patagônia é caracterizada pela presença de espécies indicadoras de qualidade da água. O objetivo do presente estudo foi caracterizar as comunidades bentônicas em riachos associados a locais com presença de florestas de Nothofagus e com intervenção humana sem florestas de Nothofagus usando modelos nulos em ecologia, teoria unificada de biodiversidade unificada (UNTB) e método de grupo de par não ponderado com média aritmética (UPGMA). Os resultados do modelo nulo de co-ocorrência de espécies revelaram que as associações de espécies são aleatórias, enquanto os resultados de modelos nulos de sobreposição de nicho revelaram a presença de sobreposição de nicho. Os resultados do UNTB revelaram baixo número de espécies. Os resultados da UPGMA demonstraram que a composição de espécies é específica para cada local, existindo diferenças marcadas. Os resultados expostos concordam com os resultados observados para os rios chileno central e norte da Patagônia, onde a composição das espécies é variável de acordo com as propriedades da bacia circundante e às condições sazonais.

PALAVRAS-CHAVE. Macroinvertebrados bentônicos, Nothofagus, comunidades, modelos nulos, insetos aquáticos.

The aquatic invertebrates in Chilean inland waters are characterized by its marked endemism (OYANEDEL et al., 2008; Moya et al., 2009; De Los Ríos-Escalante et al., 2013) at different spatial scales, becoming marked microendemism situations (PaLma et al., 2013). The benthic species composition is variable in function of geographical conditions (PALMA et al., 2013), and water quality due changes in their surrounding basin, specifically native forest replace by agricultural, urban and industrial towns (FigUEROA et al., 2003, 2007; ENCINA et al., 2017; VEGA et al., 2017) or fish predation (Кото et al., 2006, 2007; VARGAS et al., 2010; ENCINA et al., 2017; VEGA et al., 2017)
Northern Patagonian rivers can have mixture regime, it is originated by winter rains and summer snow smelt, or originated by lake effluents (NIEMEYER \& CERECEDA, 1984; ENCINA et al., 2017). In Araucania region $\left(38^{\circ} \mathrm{S}\right)$, it is possible found both kinds of rivers (ENCINA et al., 2017), and many of these rivers have surrounding basins with Nothofagus dombeyi (Mirb.) Oerst. perennial native forest or with agricultural, urban and industrial zones (VEGA et al., 2017), also many of these rivers and streams have introduced salmonids populations that generate marked alterations in benthic communities (ENCINA et al., 2017; VeGA et al., 2017). In this context, the rivers and lakes of Araucania region in 
mountain zones have marked presence of native forest, that would generate a kind of pristine condition of these habitats with marked differences in comparison to sites without native forest in their surrounding basin (DE LOS Ríos \& RoA, 2010; De los Ríos-Escalante, 2010).

The presence of native forest in Andean zones of Araucania region $\left(38^{\circ} \mathrm{S}\right)$ would be an important determinant of water quality in associated rivers and lakes (PEDrozo et al., 1993; DE Los Ríos-EsCALANTE, 2010), that in consequence would affects the aquatic communities such as was observed for pelagial environment (DE LOS Ríos-EsCALANTE et al., 2012). There are not published information about benthic fauna in Araucania region $\left(38^{\circ} \mathrm{S}\right)$ among river beds, only there are an inventory without site specifications of macroinvertebrate fauna in Cautin river (VEGA et al., 2020), Crustacean in Tolten river (DE LOS RIOS-EscALANTE et al., in press) and descriptions of benthic macroinvertebrates as preys on native fishes in Tolten river (BARILE et al., in press). Then there are not studies on variations on benthic fauna in Araucania region among riverbeds and in this context, the aim of the present study is to analyse the benthic communities in sites of a mountain stream with two kinds of surrounding basins, $N$. dombeyi native perennial forest and mixture of native forest with agricultural zones in Araucania region $\left(39^{\circ} \mathrm{S}\right.$, North Patagonia). As hypothesis, it suggest that benthic community would change in function of kind of surrounding basin in a gradient of native perennial forest, transition between perennial forest and agricultural zones.

\section{MATERIAL AND METHODS}

Study site. The sub-basins analyzed belong to the high zones of Quepe river basin that is located in centralsouthern Chile (38 $40^{\prime} \mathrm{S} ; 71^{\circ} 45^{\prime} \mathrm{W}$, Fig. 1). The area has a pluvial regime $(3800 \mathrm{~mm})$ and with snow (LUEBERT \& PLISCOFF, 2006). It has a warm-rainy template climate with Mediterranean influence and cold-rainy template with Mediterranean influence in high zones with low temperature dominance every year. The soils are deep with good drainage and muddy texture with null to weak erosion in his surface (CIREN-CORFO, 2002). In its high zone, it found native forest, in its median and low zone there are soils with agricultural and poultry zones.

Field work. Three sites with Nothofagus forest and two with mixed (Nothofagus and agriculture use) were sampled (Fig. 1); benthic macroinvertebrates were collected using a $50 * 50 \mathrm{~cm}$ Surber net of $80 \mathrm{~mm}$ mesh size, samples were collected on triplicate, in according to the descriptions of FIGUEROA et al. (2003, 2007), the collected benthic specimens were fixed with absolute ethanol, identified with specialized literature at low possible taxonomic level, that was family or genus (GonzÁLEZ, 2003; DomínGUEZ \& FERNÁNDEZ, 2009).

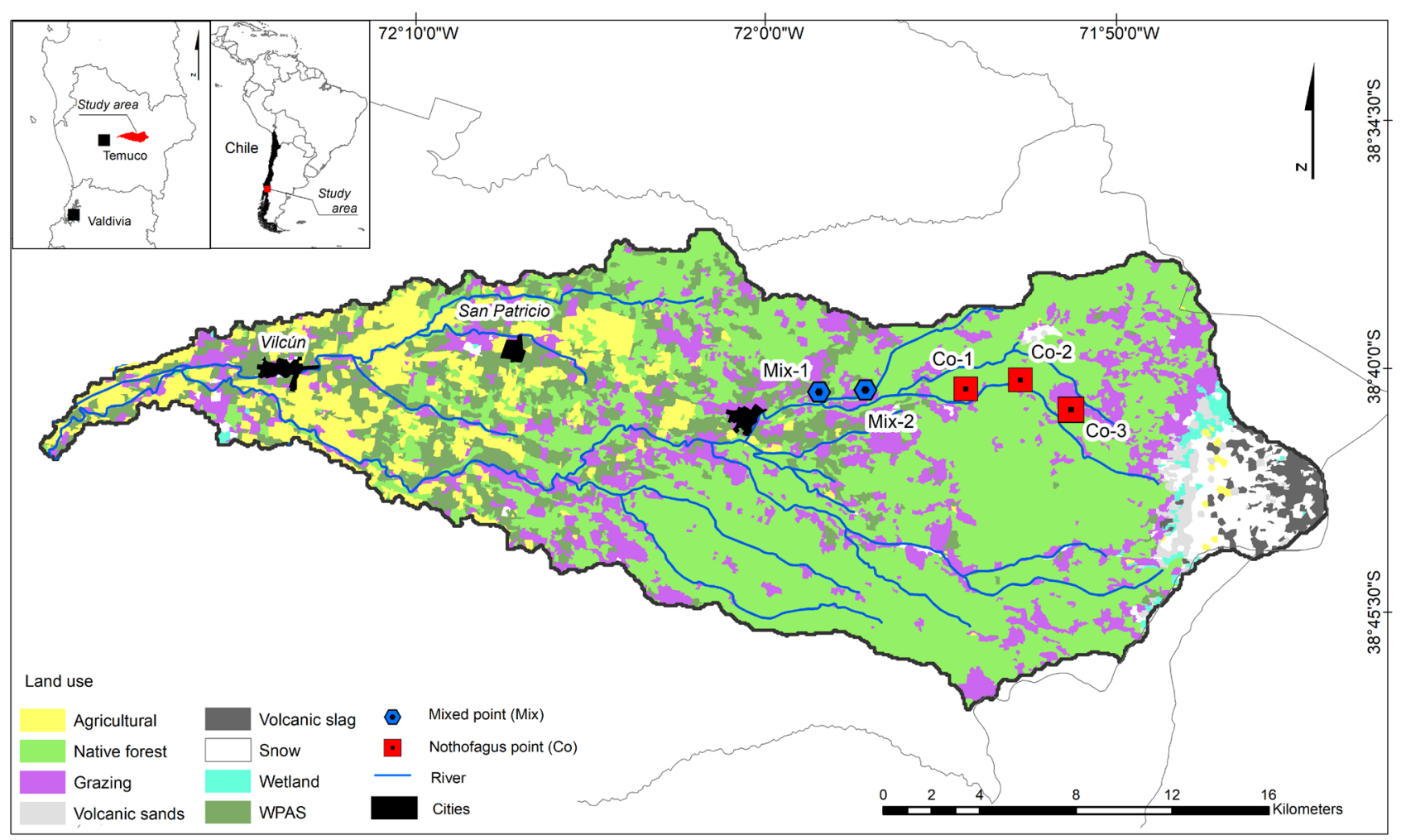

Fig 1. Map with studied site in Araucania region, Chile (Mix-1, Mixed P1; Mix-2, Mixed P2; Co-1, Coigüe P1; Co-2, Coigüe P2; Co-3, Coigüe P3). 
Data analysis. A species absence/presence matrix was constructed, with the species in rows and the sites in columns. We calculated the Checkerboard score ("C-score"), which is a quantitative index of occurrence that measures the extent to which species co-occur less frequently than expected by chance (GoTeLLI, 2000). A community is structured by competition when the C-score is significantly larger than expected by chance (GoTelli, 2000; TONDOH, 2006; TiHO $\&$ JoHENS, 2007). In addition, we compared co-occurrence patterns with null expectations via simulation. GoTELLI \& ELLison (2013) suggested the Fixed-Fixed model as statistical null model; in this model the sums of the rows and columns of the matrix are preserved. Thus, each random community contains the same number of species as the original community (fixed column), and each species occurs with the same frequency as in the original community (fixed row). The null model analyses were performed using " $R$ " software (R CORE TEAm, 2009) and the package EcosimR version 7.0 (Gotelli \& Ellison, 2013; CARVAJAL-Quintero et al., 2015).

As second step were analysed under a niche-sharing null model using Pianka's overlap index with retained niche breadth and reshuffled zero states using " $R$ " software (R CORE TEAM, 2009) and the package EcosimR version 7.0 (Gotell \& Ellison, 2013; Carvajal-Quintero et al., 2015). The EcosimR program also determines whether measured overlap values differ from what would be expected in a random sampling of the species data. EcosimR performs Monte Carlo randomisations to create pseudo-communities and then statistically compares the patterns of these randomised communities with those in the real data matrix (GoTELLI \& ELLISON, 2013). In our analysis all values of the general matrix were randomised 1000 times and the niche breadth was retained for each species; in this way, the algorithm retained the amount of specialization for each species (GoTELLI \& Ellison, 2013; Carvajal-Quintero et al., 2015). In a second step we applied UPGMA cluster analysis using the neighbour-joining method to determine potential similarities between sites on the base of species associations using " $R$ " software (R CORE TEAM, 2009) and the R package phangorn (SCHLIEP, 2018).

In a third step, it was applied analysis on the view point of unified neutral theory of biodiversity (UNTB; HUBBELL, 2001) using the R package UNTB (HANKIN, 2018), it was applied the $\theta$ estimator and Preston analysis. Finally, the data were ordered to make species richness estimations considering the presence-absence data using Chao 2, Jackknife 1 and Jackknife 2 indexes with "R" software (R Core Team, 2009) and the R package fossil (Vavrek, 2011) with the aim of understanding the community properties (Chao, 1984; Gotelli \& ChaO, 2013).

\section{RESULTS}

The results revealed that for autumn samples, Gastropoda appears a Mixed P2, whereas Oligochaeta appears only in Coigüe P1; Ephemeroptera, specifically Nesameletidae, in sites Coigüe P1-Mixed P1 is most abundant; Diptera, has low abundance only with Athericidae at site Coigüe P3, increase at site Coigüe P2, decreasing in sucessive low sites; Megaloptera (Corydalidae and Sialidae) appear at Coigüe P1 (Tab. I). In order Plecoptera, Gripopterygidae is the most abundant appearing in four sites, the second dominant is Austroperlidae with two sites, the most abundance was in Coigüe P2 and Mixed P1; Trichoptera more abundant was Smicridea that was abundant n Coigüe P1, Coigüe P2, Mixed P2, also, Ecnomidae was present in Coigüe P3 and Mixed P1, and Sericostomatidae was present in Mixed P2; Crustacea, has only Hyalella chiloensis at Coigüe P1 (Tab. I).

In winter, Oligochaeta was present with high abundance at MX2, and low abundances in decreasing order at Coigüe P1 and Coigüe P3; Ephemeroptera was most abundant with high diversity at all Coigüe sites, with high diversity at Coigüe $\mathrm{P} 1$, and high abundance at Coigüe P3, and in Mixed sites was only Notonemouridae with low abundance (Tab. I). The order Diptera has high diversity in Coigüe $\mathrm{P} 1$, and high abundance in Coigüe $\mathrm{P} 3$, whereas in Mixed sites it has low abundances; the order Megaloptera, was present only in Mixed P2; Plecoptera has high diversity at site Coigüe P1, and high abundance at Coigüe P2, decreasing its abundance at Mixed sites; finally order Trichoptera, genus Smicridea (Hydropsychidae) was present in all sites being abundant in Coigüe P2 site (Tab. I).

The results revealed a high species number and individual abundances for autumn samples in comparison to winter samples, also the sites with $N$. dombeyi has high species and individual abundances in comparison to sites with mixture of native forest with agricultural zones (Tabs I, II). The results of null model analysis revealed that species associations are random and there is niche overlapping for both sampling periods (Tabs I, II).

The UPGMA revealed for winter a marked similarity between native forest 2 with mixed 2, continuing native forest 3 , mixture 3 and native forest 1 ; whereas for autumn it was marked similarity between native forest 2 and 3 , and successively with mixture 3 , native forest 1 and mixture 2 (Fig. 2). The results of UNTB revealed low species number, the optimal $\theta$ for autumn and winter was 5.72 and 3.72, 
respectively, the singletons were 4 and 2 for autumn and winter respectively, this mean that autumn has high species number that would be equivalent that each species are practically equivalent to one individual. Finally for autumn the Chao-2, Jack-1 and Jack-2 values were 42.16; 32.77 and 39.81 respectively, whereas for winter Chao-2, Jack-1 and Jack-2 values were $13.25 ; 13.97$ and 12.99 respectively, that would show the low species number for winter period.

Tab. I. Macroinvertebrate abundances $\left(\mathrm{ind} / \mathrm{m}^{2}\right.$ ) for studied sites in Araucania region, Chile during Autumn and results of co-occurrence and niche sharing null model analysis.

\begin{tabular}{|c|c|c|c|c|c|c|}
\hline & & Coigüe P1 & Coigüe P2 & Coigüe P3 & Mixed P1 & Mixed P2 \\
\hline Location & & $\begin{array}{l}38^{\circ} 40^{\prime} 37^{\prime \prime} \mathrm{S} \\
71^{\circ} 54^{\prime} 29^{\prime \prime} \mathrm{W}\end{array}$ & $\begin{array}{l}38^{\circ} 40^{\prime} 12^{\prime \prime} \mathrm{S} \\
71^{\circ} 53^{\prime} 35^{\prime \prime} \mathrm{W}\end{array}$ & $\begin{array}{l}38^{\circ} 41^{\prime} 00^{\prime \prime} \mathrm{S} \\
71^{\circ} 50^{\prime} 52^{\prime \prime} \mathrm{W}\end{array}$ & $\begin{array}{l}38^{\circ} 40^{\prime} 37^{\prime \prime} \mathrm{S} ; \\
71^{\circ} 58^{\prime} 05^{\prime \prime} \mathrm{W}\end{array}$ & $\begin{array}{l}38^{\circ} 40^{\prime} 44^{\prime \prime} \mathrm{S} ; \\
71^{\circ} 57^{\prime} 25^{\prime \prime} \mathrm{W}\end{array}$ \\
\hline \multicolumn{7}{|l|}{ Gastropoda } \\
\hline & Gastropoda indet. & 0.0 & 0.0 & 0.0 & 2.0 & 0.0 \\
\hline \multicolumn{7}{|l|}{ Oligochaeta } \\
\hline & Oligochaeta indet. & 2.7 & 0.7 & 0.7 & 0.0 & 0.7 \\
\hline \multicolumn{7}{|l|}{ Ephemeroptera } \\
\hline & Baetidae & 0.0 & 0.0 & 3.3 & 0.0 & 0.0 \\
\hline & Coloboruscidae & 0.3 & 0.0 & 0.0 & 0.0 & 0.0 \\
\hline & Leptophlebiidae & 0.0 & 0.3 & 0.0 & 0.0 & 0.0 \\
\hline & Nesameletidae & 27.7 & 18.0 & 15.0 & 27.3 & 9.0 \\
\hline \multicolumn{7}{|l|}{ Diptera } \\
\hline & Athericidae & 1.3 & 6.7 & 4.7 & 1.0 & 0.0 \\
\hline & Ceratopogonidae & 0.3 & 0.0 & 0.0 & 2.0 & 0.0 \\
\hline & Culicidae & 0.0 & 0.0 & 0.0 & 0.3 & 0.0 \\
\hline & Chironomidae & 6.0 & 3.0 & 0.0 & 3.3 & 2.0 \\
\hline & Psychocidae & 3.7 & 0.3 & 0.0 & 0.3 & 0.0 \\
\hline & Simulidae & 3.7 & 6.0 & 0.0 & 0.0 & 0.7 \\
\hline \multicolumn{7}{|l|}{ Megaloptera } \\
\hline & Corydalidae & 0.0 & 0.0 & 0.0 & 0.7 & 0.0 \\
\hline & Sialidae & 0.0 & 0.0 & 0.0 & 1.0 & 0.0 \\
\hline \multicolumn{7}{|l|}{ Plecoptera } \\
\hline & Austroperlidae & 0.0 & 1.3 & 0.0 & 0.3 & 0.0 \\
\hline & Diamphipnoidae & 0.0 & 0.0 & 0.0 & 1.7 & 0.0 \\
\hline & Eustheniidae & 0.0 & 0.0 & 0.0 & 0.0 & 0.3 \\
\hline & Gripopterygidae & 0.0 & 1.3 & 1.7 & 1.0 & 0.0 \\
\hline \multicolumn{7}{|l|}{ Trichoptera } \\
\hline & Smicridea sp. & 7.3 & 21.0 & 18.0 & 17.3 & 2.7 \\
\hline & Ecnomidae & 0.0 & 0.0 & 4.0 & 1.3 & 0.0 \\
\hline & Sericostomatidae & 0.0 & 0.0 & 0.0 & 0.0 & 0.3 \\
\hline \multicolumn{7}{|l|}{ Crustacea } \\
\hline & Hyalella chiloensis & 1.7 & 0.0 & 0.0 & 0.0 & 0.0 \\
\hline \multicolumn{7}{|c|}{ Results of null model analysis } \\
\hline & Observed index & \multicolumn{2}{|c|}{ Mean index } & Standard Effect size & \multicolumn{2}{|c|}{$\mathrm{P}$} \\
\hline Species co-occurrence & 0.813 & \multicolumn{2}{|c|}{0.800} & 0.546 & \multicolumn{2}{|c|}{0.375 n.s } \\
\hline Niche sharing & 0.299 & \multicolumn{2}{|c|}{0.324} & 0.501 & \multicolumn{2}{|c|}{$0.240 \mathrm{n} . \mathrm{s}$} \\
\hline
\end{tabular}


Tab. II. Macroinvertebrate abundances (ind $/ \mathrm{m}^{2}$ ) for studied sites in Araucania region, Chile during Winter and results of co-occurrence and niche sharing null model analysis.

\begin{tabular}{|c|c|c|c|c|c|c|}
\hline & & Coigüe P1 & Coigüe P2 & Coigüe P3 & Mixed P2 & Mixed P3 \\
\hline \multicolumn{7}{|l|}{ Oligochaeta } \\
\hline & Oligochaeta indet. & 2.3 & 0.0 & 0.3 & 0.0 & 13.3 \\
\hline \multicolumn{7}{|l|}{ Ephemeroptera } \\
\hline & Ameletopsidae & 0.3 & 0.0 & 6.0 & 0.0 & 0.0 \\
\hline & Coloboriscidae & 2.7 & 0.0 & 0.0 & 0.0 & 0.0 \\
\hline & Notonemouridae & 2.0 & 3.3 & 4.0 & 0.3 & 0.3 \\
\hline \multicolumn{7}{|l|}{ Diptera } \\
\hline & Athericidae & 0.3 & 1.3 & 0.3 & 1.0 & 0.0 \\
\hline & Chironomidae & 1.0 & 1.0 & 0.0 & 0.3 & 0.3 \\
\hline & Psychocidae & 0.3 & 0.0 & 2.0 & 0.7 & 0.0 \\
\hline & Simulidae & 0.3 & 0.0 & 0.7 & 0.0 & 0.0 \\
\hline \multicolumn{7}{|l|}{ Megaloptera } \\
\hline & Sialidae & 0.0 & 0.0 & 0.0 & 0.0 & 0.3 \\
\hline \multicolumn{7}{|l|}{ Plecoptera } \\
\hline & Gripopterygidae & 0.7 & 0.3 & 0.0 & 0.0 & 0.0 \\
\hline & Murphyella sp. & 4.3 & 21.3 & 20.3 & 10.0 & 7.7 \\
\hline & Notoperla sp. & 0.7 & 0.0 & 0.0 & 0.0 & 0.0 \\
\hline \multicolumn{7}{|l|}{ Trichoptera } \\
\hline & Smicridea sp. & 2.0 & 20.0 & 1.3 & 4.0 & 1.7 \\
\hline \multicolumn{7}{|c|}{ Results of null model analysis } \\
\hline & Observed index & \multicolumn{2}{|c|}{ Mean index } & Standard Effect Size & \multicolumn{2}{|c|}{$P$} \\
\hline Species co-occurrence & 1.842 & \multicolumn{2}{|c|}{1.807} & 0.795 & \multicolumn{2}{|c|}{$0.230 \mathrm{n} . \mathrm{s}$} \\
\hline Niche sharing & 0.377 & \multicolumn{2}{|c|}{0.377} & 3.536 & \multicolumn{2}{|c|}{0.407 n.s } \\
\hline
\end{tabular}

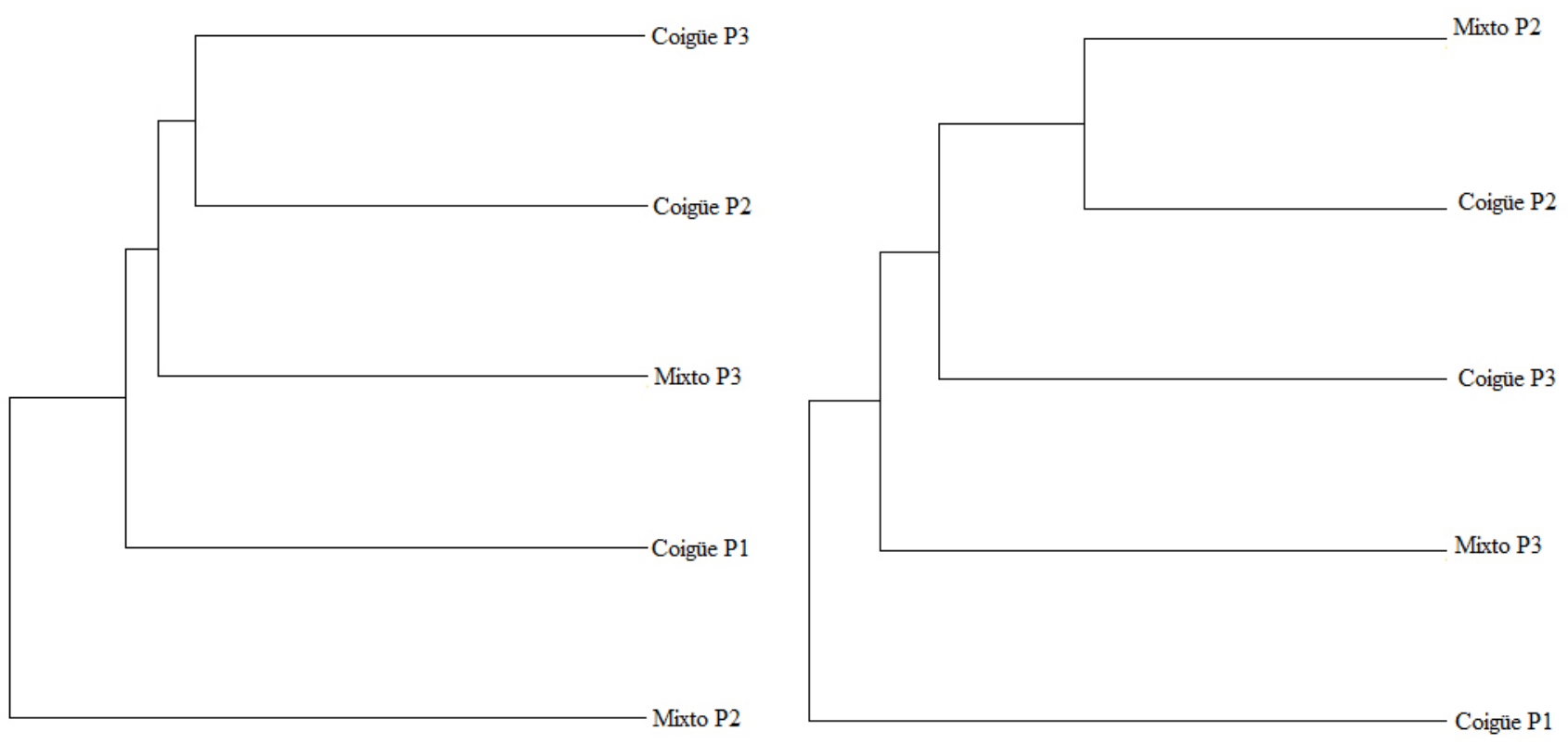

Fig 2. Results of UPGMA for autumn (left) and winter (right) data of macroinvertebrates studied at Araucaria Region, Chile. 


\section{DISCUSSION}

The exposed results would agree with observations for southern-central Chilean rivers that has a marked differences in their composition in according to the human intervention of the surrounding basin, specifically the marked abundance of shredders groups such as Ephemeroptera, Plecoptera and Trichoptera in zones with low human intervention and native forest, where there are many particulated organic matter (Fierro et al., 2012, 2015; FigueroA et al., 2003, 2007; ENCINA et al. 2017; VEGA et al., 2017). A different situation was reported for sites with mixture of native forest and human intervention, where the mentioned groups were scarce, and Diptera increase its abundances (FIGUEROA et al., 2003, 2007, $2010,2013)$. Then, on the view point of continuum river, there is a marked gradient between macroinvertebrate fauna in the origin of the riverbed, that was changes gradually in the medium and low zones of the riverbed, that was described with details for central Chilean rivers (FIGUEROA et al., 2003, 2007) and Patagonian Argentinean rivers (MisERENDINO et al., 2011, 2018).

In this scenario, the presence of a wide gradient of water quality parameters and the presence of potential predator fishes that predate on benthic invertebrates would regulate the benthic community structure (FIERRO et al., 2016; ENCINA et al., 2017; VEGA et al., 2017, 2020; BARILE et al., in press). Similar results have been reported also for Argentinean Patagonia where it is possible found rivers with native forest, and differents kind of human intervention (Miserendino, 1995,1999, 2001; Miserendino et al., 2011, 2018; PessacQ \& Miserendino, 2008), and for rivers in pristine zone in southern Chilean Patagonia (MoYA et al., 2009; OYADEDEL et al., 2008).

The results obtained in the present study, were collected in mountain zone, three stations in zone with native forest without human intervention, and two stations in a zone with human intervention, revealing the marked differences in benthic fauna, these results were similar to descriptions for mountain rivers in Catamarca, in northern Argentinean Andes (Colla et al., 2013) and Rio Grande do Sul in Brazil (BERTASo et al., 2015). The exposed results are different to other descriptions of Chilean rivers, because, these studies were conducted in rivers bed with a marked human intervention gradient without include mountain zones where is located the riverbed origin (FIGUEROA et al., 2003, 2007), perhaps, the similarities would be with studies in coastal mountain rivers with altered basins due agriculture and forestry activities between $38-39^{\circ} \mathrm{S}$ (FIERRO et al., 2012, 2015).

If it is considered in first instance the marked endemism in benthic species fauna (Domínguez \& FERNÁNDEZ, 2009), and the complex trophic interactions due abiotic environmental parameters and fish predation
(FIERRo et al., 2016; ENCINA et al., 2017; VeGA et al., 2017; BARILE et al., in press), it would explain the null model results observed in the present study: first the absence of structured pattern of species co-occurrence null model, and second the absence of niche segregation for both sampled periods. These results would indicate that it would be necessary more studies about trophic interactions in benthic fauna (INGS et al., 2009; WoODWARD et al., 2010; GRAY, 2005). Also, the role of shredders as main abundant component in benthic communities was reported for Andean rivers and would agree with the results of the present study (SCHMID-ARAYA et al., 2012).

Acknowledgements. The authors thanks and acknowledges FONDECYT INCIACIÓN N ${ }^{\circ} 11160650$ (ANID ex - CONICYT); Patricio De los Ríos thanks and acknowledges project MECESUP UCT-0804, and Technical Faculty of Catholic University of Temuco, the authors express their gratitude to M.I. and S.M.A. for their valuable comments for improve the manuscript.

\section{REFERENCES}

Bertaso, T. R. N.; Spies, M. R.; Kotzian, C. B. \& Flores, M. L. T. 2015. Effects of forest conversion on the assemblages' structure of aquatic insects in subtropical regions. Revista Brasileira de Entomologia 59(1):43-49.

Barile, J.; VegA, R. \& De Los Rios, P. First report the role of benthic macroinvertebrates as preys for native fish in Toltén river $\left(38^{\circ} \mathrm{S}\right.$, Araucania region Chile). Brazilian Journal of Biology. In press

Carvajal-Quintero, J. D.; Escobar, F.; Alvarado, F.; Villa-Navarro, F. A.; Jaramillo-Villa, U. \& Maldonado-Ocampo, J. A. 2015. Variation in freshwater fish assemblages along a regional elevation gradient in the northern Andes, Colombia. Ecology and Evolution 5(13):2608-2620.

CHAO, A. 1984. Non-parametric estimation of the number of classes in a population. Scandinavian Journal of Statistics 11(4):265-270.

CIREN-CORFO. 2002. Estudio Agrológico IX Región. Descripciones de suelos: materiales y símbolos. 343p. (Publicación CIREN 122).

COlla, M. F.; CÉSAR, I. I. \& SALAs, L. B. 2013. Benthic insects of the El Tala River (Catamarca, Argentina): longitudinal variation of their structure and the use of insects to assess water quality. Brazilian Journal of Biology 73(2):357-366.

De los Ríos, P. \& RoA, G. 2010. Crustacean species assemblages in mountain shallow ponds: Parque Cañi (38 ${ }^{\circ} \mathrm{S}$ Chile). Zoologia 27(1):81-86.

De los Ríos-Escalante, P. 2010.Crustacean zooplankton communities in Chilean inland waters. Crustaceana Monographs 12:1-109.

De los Ríos-Escalante, P.; Hauenstein, E.; Romero-Mieres, M. \& ACEVEDO, P. 2012. Use of null models to explain crustacean zooplankton assemblages in waterbodies of alerce andino national park $\left(41^{\circ} \mathrm{s}\right.$, Chile). Crustaceana 85(6):713-722.

De los Ríos-Escalante, P.; Meruane, J.; Morales, M. C.; Rudolph, E.; Fuentealba, C. \& Boxshall, G. 2013. Zoogeography of Chilean inland water crustaceans. Latin American Journal of Aquatic Research 41(5):846-853.

De los Rios-Escalante, P.; Solis, K., Rodriguez, R.; \& Farias, J. First reports on seasonal abundance of malacostracans in Allipen river ( $38^{\circ} 51^{\prime}$ S, Araucania region, Chile). Crustaceana. In press.

Domínguez, E. \& Fernández, H. R. eds. 2009. Macroinvertebrados bentónicos sudamericanos. Sistemática y Biología. San Miguel de Tucumán, Fundación Miguel Lillo. 656p.

Encina, F.; Vega, R.; Lara, G. \& De los Ríos-Escalante, P. 2017. Ecological role of benthic crustaceans in Chilean north Patagonian lakes and rivers (Araucania region, 39 $\mathrm{S}$ ). Crustaceana 90(4):437-447.

Fierro, P.; Beltrán, C.; Mercado, M.; Peña-Cortés, F.; Tapia, J.; Hauenstein, E. \& VARGas-ChaCOFF, L. 2012. Benthic macroinvertebrate assemblages as indicators of water quality applying a modified biotic 
index in a spatio-seasonal context in a coastal basin of Southern Chile. Revista de Biología Marina y Oceanografía 47(1):21-33.

Fierro, P.; Beltrán, C.; Mercado, M.; Peña-Cortés, F.; Tapia, J.; Hauenstein, E.; Caputo, L. \& Vargas-ChacofF, L. 2015. Landscape composition as determinant of diversity and functional feeding groups of aquatic macroinvertebrates in southern rivers of the Araucania, Chile. Latin American Journal of Aquatic Research 43(1): 186-200.

Fierro, P.; Quilodrán, L.; Beltrán, C.; Arismendi, I.; TaPia, J.; PeÑaCortés, F.; Hauenstein, E.; Arriagada, R.; Fernández, E. \& VARGAS-CHACOFF, L. 2016. Rainbow trout diets and macroinvertebrates assemblages responses from watersheds dominated by native and exotic plantations. Ecological Indicators 60:655-667.

Figueroa, R.; Bonada, N.; Guevara, M.; Pedreros, P.; Correa-Araneda, F.; DíAz, M. E. \& Ruiz, V. H. 2013. Freshwater biodiversity and conservation in Mediterranean climate streams of Chile. Hydrobiologia 719(1):269-289.

Figueroa, R.; Palma, A.; Ruiz V. \& Niell, X. 2007. Análisis comparativo de índices bióticos utilizados en la evaluación de la calidad de aguas en un río mediterráneo de Chile, río Chillán, VIII región. Revista Chilena de Historia Natural 80(2):225-242.

Figueroa, R.; Ruiz, V. H.; Berríos, P.; Palma, A.; Villegas, P. \& AndreuSOLER, A. 2010.Trophic ecology of native and introduced fish species from Chillan river, south-central Chile. Journal of Applied Ichthyology 26(1):78-83.

Figueroa, R.; Valdovinos, C.; Araya, E. \& Parra, O. 2003 Macroinvertebrados bentónicos como indicadores de calidad de agua de ríos del sur de Chile. Revista Chilena de Historia Natural 76(2):275-285

GonzÁLEz, E. 2003.The freshwater amphipods Hyalella Smith, 1874 in Chile (Crustacea: Amphipoda). Revista Chilena de Historia Natural 76(4):623-637.

GotelLi, N. J. 2000. Null model analysis of species co-occurrence patterns. Ecology 81(9):2606-2621

Gotelli N. J. \& Chaо, A. 2013. Measuring and Estimating Species Richness, Species Diversity, and Biotic Similarity from Sampling Data. In: Levin, S.A. ed. Encyclopedia of Biodiversity, 2ed. Waltham, Academic Press.V. 5, p.195- 211.

Gotelli, N. J. \& Ellison, A. M. EcoSimR 1.00. 2013. Available at $<$ http:// www.uvm.edu/ ngotelli/EcoSim/EcoSim.html $>$. Accessed on 01th August, 2019.

GraY, B. R. 2005. Selecting a distributional assumption for modeling relative densities of benthic macroinvertebrates. Ecological Modelling 185(1):1-12.

Hankin, R. K. S. 2018. Package "untb". Available at $<$ https://cran.r-project. org/web/packages/untb/untb.pdf $>$. Accessed on 01 th August, 2019.

Hubbell, S. P. 2001.The Unified Theory of Biodiversity and Biogeography. Princeton, Princeton University Press. 375p.

Ings, T. C.; Montoya, J. M.; Bascompte, J.; BlÜthgen, N.; Brown, L.; Dormann, C. F.; Edwards, F.; Figueroa, D.; Jacob U.; Jones, J. I.; Lauridsen, R. B.; Ledger, M. E.; Lewis H. M. \& Olesen, J. M. 2009. Ecological networks - beyond food webs. Journal of Animal Ecology 78(1):253-269.

LuEbert, F. \& Pliscoff, P. 2006. Sinopsis bioclimática y vegetacional de Chile. Santiago de Chile, Editorial Universitaria. 316p.

Miserendino, M. L. 1995. Composición y distribución del macrozoobentos de un Sistema lótico andino-patagónico. Ecologia Austral 5(2):133-142.

Miserendino, M. L. 1999. Distribución altitudinal de especies de Trichoptera en un sistema fluvial en Patagonia. Ecología Austral 9(1/2):28-34.

Miserendino, M. L. 2001. Macroinvertebrate assemblages in Andean Patagonian rivers and streams: environmental relationships. Hydrobiologia 444(1/3):147-158.

Miserendino, M. L.; Casaux, R.; Archangelsky, M.; Di Prinzio, C.Y.; BRAND C. \& KuTSChKer, A. M. 2011. Assessing land-use effects on water quality in-stream habitat, riparian ecosystems and biodiversity in Patagonian northwest streams. Science of Total Environment 409(3):612-624.

Miserendino, M. L.; Brand, C.; Epele, L. B.; Di Prinzio, C. Y.; Omad, G. H.; ArChangelski, M.; Martínez O. \& KutschKer, A. M. 2018. Biotic diversity of benthic macroinvertebrates at contrasting glacier-fed systems in Patagonia mountains: the role of environmental heterogeneity facing global warming. Science of Total Environment 622/623:152163.

Moya, C.; Valdovinos, C.; Moraga, A.; Romero, F.; Debels, P. \& Oyanedel, A. 2009. Patrones de distribución espacial de ensambles de macroinvertebrados bentónicos de un sistema fluvial Andino Patagónico. Revista Chilena de Historia Natural 82(3):425-442.

Niemeyer, H. \& Cereceda, P. 1984. Hidrografia. Santiago de Chile, Instituto Geográfico Militar. 320p.

Oyanedel, A.; Valdovinos, C.; Azocar, M.; Moya, C.; Mancilla, G.; Pedreros P. \& Figueroa, R. 2008. Patrones de distribución espacial de los macroinvertebrados bentónicos de la cuenca del río Aysen (Patagonia Chilena). Gayana 72(2):241-257.

Pedrozo, F.; Chillrud, S.; Temporetti, P. \& Díaz, M. 1993. Chemical composition and nutrient limitation in river and lakes of northern Patagonian Andes ( $\left.39.5-42^{\circ} \mathrm{S}, 71^{\circ} \mathrm{W}\right)$ (Rep. Argentina). Verhandlungen International Vereinung Angewaldte Limnologie 25:207-214.

Palma, A.; González-Barrientos, J.; Reyes, C. A. \& Ramos-Jiliberto, R. 2013. Biodiversidad y estructura comunitaria de ríos en las zonas árida, semiárida y mediterránea-norte de Chile. Revista Chilena Historia Natural 86(1):1-14.

PessacQ, P. \& Miserendino, M. L. 2008. Ephemeroptera and Plecoptera biodiversity in central Patagonia, Chubut province, Argentina. Zootaxa 1817:27-38.

R Development Core Team. 2009. R: A language and environment for statistical computing. R Foundation for Statistical Computing, Vienna, Austria.

SCHLIEP, K. 2018. Package "phangorn". Available at $<$ https://cran.r-project. org/web/packages/phangorn/phangorn.pdf $>$. Accessed on 01 th August, 2019.

Schmid-Araya, J. M.; Figueroa, D.; Schmid P. E. \& Drouot, C. 2012. Algivory in food webs of three temperate Andean rivers. Austral Ecology 37(4):440-451.

Soto, D.; Arismendi, I.; Gonzalez, J.; Sanzana, J.; Jara, F.; Jara, C.; GuZman, E. \& LARA, A. 2006. Sur de Chile, país de truchas y salmones: patrones de invasión y amenazas para las especies nativas. Revista Chilena Historia Natural 79(1):97-117.

Soto, D.; Arismendi, I.; Prinzio C.; \& JARA, F. 2007. Establishment of Chinook salmon (Oncorhynchus tshawytscha) in Pacific basins of southern South America and its potential ecosystem implications. Revista Chilena Historia Natural 80(1):81-98.

Tiнo, S. \& Johens, G. 2007. Co-occurrence of earth worms in urban surroundings: a null model analysis of community structure. European Journal of Soil Biology 43(2):84-90.

TonDOH, J. E. 2006. Seasonal changes in earthworm diversity and community structure in Central Côte d'Ivoire. European Journal of Soil Biology 42(Suppl.1):334-340.

Vargas, P.V.; Arismendi, I.; Lara, G.; Millar, J. \& Peredo, S.; 2010. Evidencia de solapamiento de micro-habitat entre juveniles de salmón introducido Oncorhynchus tshawytscha y el pez nativo Trichomicterus aerolatusen el río Allipén, Chile. Revista de Biología Marina y Oceanografía 45(2):285-292.

VAVReK, M. J. 2011. Fossil: palaeoecological and palaeogeographical analysis tools. Palaeontologia Electronica 14:1T.2011. Available at $<$ http://palaeo-electronica.org/2011 1/238/index.html >. Accessed on 01th August, 2019.

Vega, R.; De los Ríos-Escalante, P.; Encina F. \& Mardones, A. 2017. Ecology of benthic crustaceans in the Cautin river $\left(38^{\circ} \mathrm{S}\right.$, Araucania region, Chile). Crustaceana 90(6):709-719. 